\title{
Konsep Pengembangan Agribisnis Nanas (Ananas Comosus L. Merr.) Di Kabupaten Kediri Provinsi Jawa Timur
}

\section{Concept Pineapple (Annas Comusus L. Merr.) Agribusiness Development In Kediri Regency of East Java Province}

\author{
Endro Puji Astoko* \\ *Jurusan Agribisnis, Fakultas Pertanian, Universitas Islam Kadiri, Jl. Sersan Suharmaji No.38, \\ Manisrenggo Kecamatan Kota, Kediri, Indonesia
}

Diterima: 26 Agustus 2019; Direvisi: 22 November 2019; Disetujui: 1 Desember 2019

\begin{abstract}
ABSTRAK
Nanas (Ananas Comosus L.Merr.) merupakan salah satu buah tropis yang banyak diminati baik di dalam maupun di luar negeri. Ekspor buah nanas tahun 2008 sebesar 204.552.168 dan nilai (US\$) ekspor buah nanas tahun 2012 hanya sebesar 132.015.559. Tujuan 1) mengetahui faktor yang mempengaruhi strategi pengembangan agribisnis nanas, 2) mengetahui strategi yang mempengaruhi pengembangan agribisnis. Penelitian di Desa Ngancar, Manggis, Sempu, Sugihwaras dan Babadan di Kecamatan Ngancar, Kabupaten Kediri. Waktu penelitian bulan Nopember 2013 sampai bulan April 2014. Metode kualitatif dengan studi kasus. Total sample adalah 15 petani. Analisis menggunakan SWOT. Hasil penelitian, (1) Agroekologi cocok dipadukan dengan kualitas sumber daya manusia akan mampu menghasilkan buah nanas unggul berkualitas dan kontinuitas, (2) Ketersediaan bibit hasil penangkaran sendiri yang unggul, ketersediaan lahan, pengembangan varietas baru yang dipadukan dengan adopsi teknologi kultur jaringan akan mampu menciptakan nanas unggul berkualitas dan kontinuitas.(3) Produksi nanas yang unggul harus didukung oleh ketersediaan sarana produksi yang memadai, kelembagaan petani yang mantap dan profesional serta kebijakan pemerintah yang memihak kepada petani nanas. (4) Strategi pemasaran yang tepat sasaran, adanya industri pengolahan nanas serta didukung kebijakan moneter yang menguntungkan bagi petani nanas.
\end{abstract}

Kata Kunci: Analisis SWOT; Konsep Pengembangan nanas; Strategi Pengembangan agribisnis

\section{ABSTRACT}

Pineapple (Ananas Comosus L.Merr.) is a tropical fruit that is in great demand both at home and abroad. Pineapple fruit exports in 2008 amounted to 204.552.168 and the value (US\$) of pineapple exports in 2012 was only 132,015,559. Objectives 1) determine the factors that influence pineapple agribusiness development strategies, 2) know the strategies that affect agribusiness development. Research in Ngancar, Manggis, Sempu, Sugihwaras and Babadan Villages in Ngancar District, Kediri Regency. Research time is November 2013 to April 2014. Qualitative methods with case studies. The total sample is 15 farmers. Analysis using SWOT. The results of the study, (1) Agroecology suitable to be combined with the quality of human resources will be able to produce superior quality pineapple fruit and continuity, (2) The availability of superior self-bred seedlings, land availability, the development of new varieties combined with the adoption of tissue culture technology will be able creating high-quality pineapple quality and continuity (3) Production of superior pineapple must be supported by the availability of adequate production facilities, stable and professional farmer institutions and government policies that favor pineapple farmers. (4) Targeted marketing strategies, the presence of pineapple processing industries and supported by favorable monetary policies for pineapple farmers.

Keywords: SWOT Analysis; Pineapple Development Concepts; Agribusiness Development Strategies

How to Cite:

Astoko, E. P. (2019). Konsep Pengembangan Agribisnis Nanas ( Ananas Comosus L . Merr . ) Di Kabupaten Kediri Propinsi Jawa Timur. HABITAT, 30(3), 111-122. https://doi.org/10.21776/ub.habitat.2019.030.3.14 


\section{Pendahuluan}

Buah nanas (Ananas comosus L. Merr.) merupakan salah satu tanaman buah yang sudah lama dikenal luas oleh masyarakat. Tanaman ini cukup mudah untuk dibudidayakan, dan iklim Indonesia pun ternyata sangat cocok untuknya. Volume ekspor nanas begitu besar sehingga Indonesia menjadi negara pengekspor nanas terbesar di dunia hingga awal tahun 2012 (Wicaksono, 2015). Peningkatan eksport buah nanas dalam kaleng juga terus meningkat seiring dengan peningkatan permintaan terutama oleh negara Amerika Serikat, Jepang, Belanda, dan negara - negara Eropa.

Sedangakan secara nasional pada tahun 1992 nasional terdapat 18.597 ha luas areal tanaman nanas yang tersebar di seluruh wilayah Indonesia artinya mengalami peningkatan akan kebutuhan, namun yang merupakan sentra produksi utama adalah Sumatera Utara, Sumatera Selatan, Lampung, Jawa barat, Jawa Timur, Sulawesi Utara, dan Kalimantan Tengah. Luas areal perkebunan rakyat tanaman nanas yang mencapai $47 \%$ dari 3,74 juta ha dan melibatkan lebih dari tiga juta rumah tangga petani. Pengusahaan nanas juga membuka tambahan kesempatan kerja dari kegiatan pengolahan produk turunan dan hasil samping yang sangat beragam jenisnya (Wicaksono, 2015)

Nanas (Ananas Comosus L. Merr) merupakan salah satu buah - buahan tropis yang banyak diminati baik di dalam negeri maupun di luar negeri. Buah nanas umumnya dikunsumsi dalam bentuk segar atau buah meja, namun dapat pula dinikmati dalam bentuk juice sebagai minuman segar ataupun dalam bentuk olahan seperti dodol, kripik nanas dan selai. Pada buah nanas terdapat enzim asam bromelain yang bermanfaat untuk kesehatan diantaranya mengurangi tekanan darah, membersihkan darah, meningkatkan pencernaan, menghambat pertumbuhan sel kanker, dan meningkatkan sistem pertahanan tubuh.

Nanas merupakan komoditi yang terbukti memiliki peluang pasar yang cukup baik di dalam maupun di luar negeri. Saat ini pemasaran buah nanas tidak hanya dalam bentuk segar tetapi juga dalam bentuk pangan olahan, misalnya nanas segar tetapi juga dalam bentuk pangan olahan,

\footnotetext{
*Penulis Korespondensi

E-mail: pujiastoko@yahoo.com

Telp: +62-821-4136-4888
}

misalnya nanas kalengan, nata de pina, jam, dodol dan lain-lain.

Eksport nanas segar Indonesia periode 1987 - 1990 terus meningkat dengan laju rata rata pertumbuhan $287,83 \%$. Volume ekspor nanas begitu besar sehingga Indonesia menjadi negara pengekspor nanas terbesar di dunia hingga awal tahun 2012 (Wicaksono, 2015). Peningkatan eksport buah nanas dalam kaleng juga terus meningkat seiring dengan peningkatan permintaan terutama oleh negara Amerika Serikat, Jepang, Belanda, dan negara - negara Eropa.

Tabel 1. Produksi dan konsumsi buah nanas tahun 2008-2012

\begin{tabular}{lclll}
\hline Thn & \multicolumn{2}{c}{ Produksi } & \multicolumn{2}{c}{ Konsumsi } \\
\cline { 2 - 5 } & Ton & $\begin{array}{c}\text { Pertumb } \\
\text { uhan } \\
(\%)\end{array}$ & Ton & $\begin{array}{c}\text { Pertum } \\
\text { buhan } \\
(\%)\end{array}$ \\
\hline 2008 & $1,433,133$ & - & 66,383 & - \\
2009 & $1,558,196$ & 0,09 & 67,412 & 0,02 \\
2010 & $1,408,445$ & 0,10 & 68,438 & 0,02 \\
2011 & $1,540,626$ & 0,09 & 69,463 & 0,01 \\
2012 & $1,749,814$ & 1,00 & 70,489 & 0,01 \\
\hline Jumlah & $7,690,214$ & - & 342,437 & - \\
\hline Rata- & $1,538,043$ & 0,23 & 68,437 & 0,02 \\
rata & & & & \\
\hline Sula
\end{tabular}

Sumber: BPS dan Direktorat Jenderal Hortikultura, 2013

Tabel 1. menunjukkan bahwa jumlah produksi buah nanas di Indonesia selama lima tahun terakhir meningkat sebesar $0,23 \%$ sehingga terjadi peningkatan konsumsi buah nanas sebesar $0,02 \%$. Jumlah produksi buah nanas terus mengalami peningkatan dalam lima tahun terakhir karena buah nanas merupakan buah yang dapat dengan mudah hidup di musim panas dan musim penghujan, sehingga kegiatan budidaya tetap dapat berjalan dengan lancar meskipun cuaca tidak stabil. Jumlah konsumsi buah nanas terus mengalami peningkatan dalam lima tahun terakhir karena jumlah penduduk Indonesia mengalami peningkatan sebesar $1,5 \%$ setiap tahunnya. Jumlah konsumsi buah nanas tersebut masih rendah dibandingkan dengan jumlah produksi buah nanas dalam lima tahun terakhir, hal ini karena masih sedikit masyarakat Indonesia yang menyukai nanas segar untuk dikonsumsi langsung serta dipengaruhi rendahnya pengetahuan penduduk Indonesia akan pentingnya mengkonsumsi buah nanas.

Badan Pusat Statistik (BPS) dan Direktorat Jenderal Hortikultura (2013) menyatakan bahwa 
nilai (US\$) ekspor buah nanas terus menurun selama lima tahun terakhir. Hal ini ditunjukkan dengan nilai (US\$) ekspor buah nanas tahun 2008 sebesar 204.552.168 dan nilai (US\$) ekspor buah nanas tahun 2012 hanya sebesar 132.015.559, sehingga terjadi penurunan nilai (US\$) ekspor buah nanas sebesar $-0,35 \%$. Peningkatan jumlah produksi buah nanas tidak diiringi dengan peningkatan permintaan buah nanas baik permintaan buah nanas di dalam negeri maupun di luar negeri, sehingga menyebabkan jumlah penawaran buah nanas lebih besar dibandingkan dengan jumlah permintaannya.

Di dalam negeri pada tahun 1992 beberapa pabrik pengolahan nanas masih kekurangan bahan baku, sehingga perlu peningkatan produksi. Kekurangan bahan baku bukan hanya karena produksi rendah, tetapi juga tidak tercapainya standar kualitas nanas untuk bahan baku pabrik. Kejadian ini pernah terjadi di daerah Subang Jawa Barat, yang mengakibatkan salah satu pabrik terpaksa tutup, dan juga didaerah kandat kediri salah satu pabrik pengalengan nenas terpaksa tutup karena pasokan bahan baku dan kualitas nanas petani kediri rendah.

Permasalahan perlu diatasi dengan dibina suatu sistem kerja sama antara pabrik dengan petani, antara eksportir dengan petani secara lebih intensif. Peningkatan pengetahuan tentang macam - macam varietas nanas dan kegunaanya perlu diusahakan. Demikian pula dengan penguasaan teknologi budidaya nanas bila dilakukan secara intensip dapat memberikan hasil sebanyak 40 ton/ha. Selain itu untuk menjaga kesinambungan produksi buah nanas dari petani, pihak perusahaan hendaknya menjamin penetapan harga yang layak.

Pemasaran buah nanas dalam negeri sering mengalami permasalahan, yakni rendahnya harga buah nanas pada saat panen raya. Permasalahan ini dapat diatasi dengan pengaturan waktu tanam dan pembungaan sehingga panen dapat diperkirakan jatuh pada saat yang tepat, sehingga produksi tidak melimpah pada satu waktu.

Tanaman nanas dapat ditanam secara monokultur ataupun polikultur bersama tanaman lain. Bagi petani yang berlahan sempit, tanaman nanas dapat ditanam secara polikultur. Pola tanam seperti ini apabila dilaksanakan dengan teknik yang benar akan memberikan hasil yang memuaskan sebagai tambahan penghasilan bagi petani.

Saat panen yang tepat perlu diketahui agar dapat dipasarkan dalam keadaan yang masih baik. Selain itu untuk mempertahankan kualitas buah, perlu penguasaan teknologi pasca panen yang tepat sehingga harga buah tidak jatuh.Sistem agribisnis merupakan penyumbang terbesar dalam pembentukan produk domestik bruto (PDB), peluang penyerapan kesempatan kerja dan ikut serta dalam peningkatan eksport. Hasil analisis Deptan (2001) menyatakan bahwa kontribusi sistem agribisnis dalam produk domestik bruto mencapai sekitar $48 \%$, dalam penyerapan tenaga kerja mencapai $77 \%$, dan dalam total ekspor menyumbang $50-80 \%$ dari nilai ekspor non migas. Sistem agribisnis juga mempunyai peran penting dalam pelestarian lingkungan hidup karena mampu meratakan penyebaran penduduk dan segala aktivitasnya sehingga dapat mencegah tekanan penduduk yang berlebihan pada daerah tertentu, tekanan penduduk dan aktivitasnya yang berlebihan hanya pada daerah tertentu dapat mengakibatkan ketidakseimbangan ekosistem karena eksploitasi yang berlebihan sehingga dapat merusak lingkungan hidup daerah tersebut, (Kagoya Been, 2009)

Salah satu komoditas yang diidentifikasi memiliki potensi bisnis yang besar untuk mencapai sasaran tersebut adalah nenas. Luas panen di Indonesia \pm 165.690 ha atau 25,24\% dari sasaran panen buah-buahan nasional (657.000 ha ). Beberapa tahun terakhir luas areal tananman nanas menempati urutan pertama dari 13 jenis buah-buahan komersial yang dibudidayakan di Indonesia (PKBT, 2007). Sejalan dengan hal tersebut, permintaan pasar dalam negeri terhadap buah nanas cenderung terus meningkat sejalan dengan pertumbuhan jumlah penduduk, makin baiknya pendapatan masyarakat, makin tingginya kesadaran penduduk akan nilai gizi dari buah-buahan. Buah nanas selain dikunsumsi segar juga dapat diolah menjadi berbagai produk makanan dan minuman, seperti nanas kaleng, selai, makanan kering, jus,spirit/pelarut, fragam selai, sari buah, keripik, sirup, dodol, konsentrat, coctail, dan lain-lain. Pemanfaatan buah nenas menjadi produk-produk industri yang mempunyai nilai tambah (value added) tersebut hanya sebagian kecil saja terealisasi dalam bentuk industri. Selain itu, limbah atau hasil ikutan (by product) kulit buah dan daun nanas belum banyak dimanfaatkan untuk industri-industri makanan, kertas, dan tekstil (Departemen Pertanian, 2007).

Pembangunan sistem agribisnis sebagai penggerak utama pembangunan ekonomi nasional (agribisnis led development) maka persoalan ekonomi Indonesia saat ini seperti 
pertumbuhan ekonomi, perluasan kesempatan kerja, peningkatan devisa, pemerataan kesejahteraan dan percepatan pembangunan ekonomi daerah yang dapat membangun ketahanan pangan serta pelestarian lingkungan hidup, seharusnya dapat dilakukan dengan baik dan dilakukan secara berkelanjutan. Sebenarnya saat ini di Kabupaten Kediri merupakan saat yang tepat untuk mengembangkan komoditi nanas melalui pembangunan sisten agribisnis perkebunan nanas milik petani.

Pada era pasca pemerintahan reformasi pembangunan, ekonomi Indonesia masih harus diarhkan pada upaya-upaya perbaikan ekonomi dengan beberapa sasaran utama pada sektor riil yang harus segera dicapai yaitu; 1. Meningkatkan pendapatan masyarakat tertama golongan ekonomi lemah melalui pemberdayaan kekuatan ekonomi rakyat; 2. Meningkatkan penerimaan devisa melalui peningkatan ekspor non migas; 3 . Menciptakan struktur industri yang kuat, yang mampu memanfaatkan keunggulan komparatif untuk mencapai keunggulan kompetitif menghadadapi persaingan global; 4. Menciptakan sektor agribisnis dan agroindustri yang tangguh sebagai landasan ekonomi indonesia menuju era industrialisasi; 5. Mencapai daya saing yang tinggi bagi produk domestik melalui peningkatan produktivitas (efektif dan efisien) dengan mempercepet inovasi dan diseminasi teknologi tepat guna yang mampu menghasilkan produk unggul mutu dan biaya; 6. Menciptakan pembangunan ekonomi rakyat yang berkelenjutan dan memenuhi kriteria ramah lingkungan (Intan ,2007).

Penyebaran nenas di Indonesia pada mulanya hanya sebagai tanaman pengisi di lahan pekarangan, tetapi lambat laun meluas dikebunkan di lahan kering (tegalan) di seluruh wilayah nusantara. Dari 27 propinsi di Indonesia, lima propinsi yang paling luas areal tanaman nenas adalah jawa Timur, sumatera Utara, Riau, Sumatera Selatan, dan Jawa Barat (Departemen Pertanian, 2007)

Varietas yang saat ini diminanti pasar modern dan pasar ekspor adalah jenis Smooth cayenne yang mempunyai rasa yang manis dan kandungan airnya lebih tinggi dibandingkan dengan nenas Queen. Perkembangan nenas Smooth Cayenne di Kabupaten Kediri berada di beberapa kecamatan dengan ketinggian tempat mulai $300-700$ m dpl di lereng Gunung Kelud, antara lain di Kecamatan Ngancar, plosoklaten, dan Puncu. Sampai dengan saat ini, pengembangan nenas di kabupaten Kediri masih didominasi oleh jenis Queen (Direktorat Budidaya Dan Pasca Panen Buah 2012).

Buah nanas merupakan salah satu komoditas andalan di Kabupaten Kediri yang masih mempunyai beberapa kelemahan dalam mengembangkan melalui sistem agribisnisnya. Kelemahan agribisnis buah di Kabupaten Kediri ialah :

1. Daya saing dengan produsen dari daerah lain sangat lemah, terutama untuk Varietas Smooth Cayenne karena tidak ada kontinuitas produksi.

2. Penanaman nanas masih dibudidayakan dengan teknologi yang relatip sederhana.

3. Teknologi produksi dan pasca panen belum dilakukan secara maksimal dalam pengelolaan kebun nanas.

4. Sistem dan strategi pemasaran masih lemah masih didominasi oleh para tengkulak dan pedagang lokal.

5. Belum adanya penerapan teknologi pasca panen yang baik.

Mengingat nanas merupakan komoditas yang memiliki nilai ekonomi yang tinggi dan merupakan produk unggulan di Kabupaten Kediri, maka perlu dicari strategi pengembangan nanas dengan harapan dapat meningkatkan pendapatan petani, sehingga pada akhirnya dapat mewujudkan kesejahteraan petani. Oleh sebab itu dilakukan penelitian ini dengan tujuan mengetahui faktor-faktor apa saja yang mempengaruhi strstegi pengembangan agribisnis nanas (Ananas comosus L. Merr.) di Kabupaten Kediri, mengatahui strategi apa yang mempengaruhi pengembangan agribisnis nanas (Ananas comosus L.Merr.) yang paling efektif dan efisien.

\section{Metode Penelitian}

Penelitian ini merupakan jenis penelitian metode metode campuran (mixed method) yaitu kualitatif dan kuantitatif. Penelitian ini dilakukan di empat desa Kecamatan Ngancar, yaitu Di Desa Ngancar, Desa Manggis, Desa Babadan, dan Desa Sempu. Kegiatan penelitian mulai dilaksanakan pada bulan Nopember 2013 sampai dengan bulan April 2014 atau selama 6 (enem) bulan. Alasan penentuan lokasi tersebut berdasarkan pertimbangan bahwa keempat desa tersebut merupakan daerah sentra penghasil nenas terbesar di Kecamatan Ngancar Kabuten Kediri. Pendekatan yang digunakan dengan studi kasus (case study), yaitu pendekatan penelitian yang menelaahnya diarahkan pada suatu kasus 
secara intensif, mendalam dan memadai serta komperhensif. Populasi dalam penelitian ini adalah petani nanas di daerah Desa Ngancar, Desa Manggis, Desa Sempu, Desa Babadan dan keseluruhan dari populasi tersebut dijadikan sebagai sampel dengan menggunakan metode sensus. Pengambilan sampel dalam penelitian ini menggunakan teknik random sampling, yaitu pengambilan sampel yang dilakukan kepada petani nenas dengan jumlah sampel sebanyak 15 orang petani yang diacak di lima desa penelitian yang memiliki populasi nanas paling luas, yaitu Desa Ngancar, Manggis, Sempu, Sugihwaras dan Babadan.

Analisis data menggunakan teknik analisis diskriptif kualitatif dengan menggunakan analisis SWOT (Strenghts, weaknesses, Opportunities, dan Threats) yang berguina sebagai alat formulasi strategi pengembangan agribisnis nanas. Dari hasil analisa faktor internal dan eksternal di lingkungan sentra agribisnis nanas di Kediri sehingga menghasilkan perumusan peluang dan ancaman yang akan dihadapi oleh petani nanas dimasa yang akan datang. Disisi lain bahwa hasil analisis lingkungan eksternal digunakan untuk melakukan introspeksi terhadap kekuatan dan kelemahan petani nanas. Analisis SWOT dilakukan melalui proses pemikiran logis dengan memaksimalkan kekuatan (strenghts) dan peluang (opportunities), namun bersama itu pula bisa meminimalkan kelemahan (weaknesses) dan ancaman (threats).

\section{Hasil dan Pembahasan}

Penelitian ini mengambil sampel sebanyak 15 orang petani nanas yang tersebar di 5 desa sentra nanas.

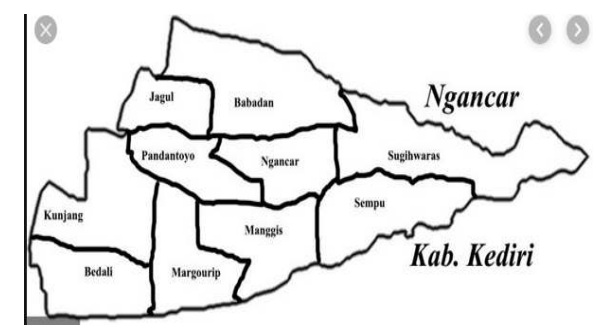

\section{Gambar 1. Peta Lokasi Penelitian}

Berdasarkan hasil penyebaran kuisioner ke 15 orang petani nanas bahwa strategi pengembangan agribisnis nanas di Kabupaten Kediri dipengaruhi oleh faktor internal yang meliputi ; kekuatan dan kelemahan serta faktor eksternal yang meliputi; peluang dan ancaman. Faktor-faktor yang mempengaruhi strategi pengembangan agribisnis nanas (Ananas comosus L. Merr.) dijelaskan dalam tabel berikut:

Tabel 2. Hasil Tanggapan Responden Faktor Kekuatan

\begin{tabular}{|c|c|c|c|c|c|c|}
\hline \multirow[t]{2}{*}{ No } & Kekuatan / Strenghts & SB & B & KB & TB & \multirow[t]{2}{*}{ Rata-rata } \\
\hline & Skor & 4 & 3 & 2 & 1 & \\
\hline & Agroekologi & 15 & & & & \multirow[t]{2}{*}{$60 / 15=4$} \\
\hline & & 60 & & & & \\
\hline & Kualitas SDM & 7 & 7 & 1 & & \multirow[t]{2}{*}{$51 / 15=3,4$} \\
\hline & & 28 & 21 & 2 & & \\
\hline \multirow[t]{2}{*}{3.} & Ketersediaan bibit & 6 & 4 & 5 & & \multirow[t]{2}{*}{$46 / 15=3$} \\
\hline & & 24 & 12 & 10 & & \\
\hline & Ketersediaan Lahan & 3 & 8 & 4 & & \multirow[t]{2}{*}{$44 / 15=2,9$} \\
\hline & & 12 & 24 & 8 & & \\
\hline & Kelembagaan Petani & 5 & 9 & 1 & & \multirow[t]{2}{*}{$49 / 15=3,2$} \\
\hline & & 20 & 27 & 2 & & \\
\hline & Kebijakan Pemerintah & & 15 & & & $45 / 15=3$ \\
\hline
\end{tabular}

Keterangan: SB: sangat baik, B: baik, KB: kurang baik, TB: tidak baik

Tabel 2. dijelaskan faktor kekuatan seperti agroekologi dan kualitas SDM dari tanggapan responden disebutkan berada pada katagori sangat baik dengan rata-rata skor sebesar \pm 4 , artinya bahwa dari aitem pertanyaan yang diajukan kepada responden memperlihatkan bahwa faktor-faktor tersebut sangat baik mempengaruhi dalam strategi pengembangan agribisnis nanas (Ananas comosus L.Merr.) di Kabupaten Kediri Jawa Timur. Faktor kualitas SDM, ketersediaan bibit hasil penangkaran sendiri,ketersediaan lahan, kelembagaan tani dan 
kebijakan pemerintah daerah dari tanggapan responden disebutkan berada pada katagori baik dengan rata-rata sebesar \pm 3 , artinya bahwa faktor-faktor tersebut baik mempengaruhi dalam strategi pengembangan agribisnis nanas (Ananas comosus L.Merr.) di Kabupaten Kediri Jawa Timur.

Tabel 3. Hasil Tanggapan Responden Faktor Kelemahan

\begin{tabular}{|c|c|c|c|c|c|c|}
\hline \multirow[t]{2}{*}{ No } & Kelemahan/ Weaknesses & SB & B & KB & $\mathrm{TB}$ & \multirow[t]{2}{*}{ Rata-rata } \\
\hline & \multirow{3}{*}{ Menejemen Usaha Tani } & 4 & 3 & 2 & 1 & \\
\hline & & 7 & 7 & 1 & & \multirow[t]{2}{*}{$51 / 15=3,4$} \\
\hline & & 28 & 21 & 2 & & \\
\hline \multirow{2}{*}{\multicolumn{2}{|c|}{ Kepemilikan lahan $<0,5$ ha }} & 5 & 9 & 1 & & \multirow[t]{2}{*}{$49 / 15=3,2$} \\
\hline & & 20 & 27 & 2 & & \\
\hline \multirow{2}{*}{\multicolumn{2}{|c|}{ 3. Permodalan / Modal Uang }} & 5 & 10 & & & \multirow[t]{2}{*}{$50 / 15=3,3$} \\
\hline & & 20 & 30 & & & \\
\hline \multirow{2}{*}{\multicolumn{2}{|c|}{ 4. Budaya Petani }} & & 4 & 11 & & \multirow[t]{2}{*}{$33 / 15=2,2$} \\
\hline & & & 12 & 22 & & \\
\hline \multirow{2}{*}{\multicolumn{2}{|c|}{ 5. $\quad$ Pemupukan Tak Berimbang }} & & 3 & 10 & 2 & \multirow[t]{2}{*}{$31 / 15=2$} \\
\hline & & & 9 & 20 & 2 & \\
\hline \multirow{2}{*}{\multicolumn{2}{|c|}{ 6. Akses Pasar terbatas }} & 1 & 12 & 2 & & \multirow[t]{2}{*}{$44 / 15=2,9$} \\
\hline & & 4 & 36 & 4 & & \\
\hline
\end{tabular}

Keterangan: SB: sangat baik, B: baik, KB: kurang baik, TB: tidak baik

Tabel 3. dapat dijelaskan faktor kelemahan seperti menejemen usaha tani nanas, Kepemilikan lahan yang kecil dan permodalan / modal uang dari tanggapan responden disebutkan berada pada katagori baik dengan rata-rata skor sebesar \pm 3 , artinya bahwa dari aitem pertanyaan yang diajukan kepada responden memperlihatkan bahwa faktor-faktor tersebut baik mempengaruhi dalam strategi pengembangan agribisnis nanas (Ananas comosus L.Merr.) di Kabupaten Kediri Jawa Timur.
Sedangkan faktor budaya petani dan pemupikan tak berimbang dari tanggapan responden disebutkan berada pada katagori kurang baik dengan rata-rata sebesar \pm 2 , artinya bahwa dari aitem pertanyaan yang diajukan kepada responden memperlihatkan bahwa faktorfaktor tersebut kurang mepengaruhi dalam strategi pengembangan agribisnis nanas (Ananas comosus L.Merr.) di Kabupaten Kediri Jawa Timur.

Tabel 4. Hasil Tanggapan Responden Faktor Peluang

\begin{tabular}{|c|c|c|c|c|c|c|}
\hline \multirow[t]{2}{*}{ No } & Peluang / Opportunities & SB & $\mathrm{B}$ & $\mathrm{KB}$ & TB & \multirow[t]{2}{*}{ Rata-rata } \\
\hline & Skor & 4 & 3 & 2 & 1 & \\
\hline \multirow{2}{*}{\multicolumn{2}{|c|}{ 1. $\quad$ Pengembangan Varietas Baru }} & 9 & 6 & & & \multirow[t]{2}{*}{$54 / 15=3,6$} \\
\hline & & 36 & 18 & & & \\
\hline \multirow{2}{*}{\multicolumn{2}{|c|}{ 2. $\quad$ Strategi Pemasaran }} & 4 & 10 & 1 & & \multirow[t]{2}{*}{$48 / 15=3,2$} \\
\hline & & 16 & 30 & 2 & & \\
\hline \multirow{2}{*}{\multicolumn{2}{|c|}{ 3. Adopsi Teknologi }} & 3 & 10 & 1 & 1 & \multirow[t]{2}{*}{$45 / 15=3$} \\
\hline & & 12 & $30^{-}$ & 2 & 1 & \\
\hline \multirow{2}{*}{\multicolumn{2}{|c|}{ 4. Sarana Produksi }} & 3 & 11 & 1 & & \multirow[t]{2}{*}{$47 / 15=3,1$} \\
\hline & & 12 & 33 & 2 & & \\
\hline \multirow{2}{*}{\multicolumn{2}{|c|}{ 5. Kebijakan Moneter }} & & 14 & & 1. & \multirow[t]{2}{*}{$43 / 15=2,8$} \\
\hline & & & $42^{-}$ & & 1 & \\
\hline \multirow{2}{*}{\multicolumn{2}{|c|}{ 6. Industri Pengolahan Hasil }} & & 3 & 11 & 1 & \multirow[t]{2}{*}{$32 / 15=2,1$} \\
\hline & & & 9 & 22 & 1 & \\
\hline
\end{tabular}

Keterangan: SB: sangat baik, B: baik, KB: kurang baik, TB: tidak baik 
Tabel 4. dapat dijelaskan faktor peluang seperti strategi pengembangan varietas baru dari tanggapan responden disebutkan berada pada katagori sangat baik dengan rata-rata skor sebesar \pm 4 , artinya bahwa dari aitem pertanyaan yang diajukan kepada responden memperlihatkan bahwa faktor-faktor tersebut sangat baik mempengaruhi dalam strategi pengembangan agribisnis nanas (Ananas comosus L.Merr.) di Kabupaten Kediri Jawa Timur.
Sedangkan faktor strstegi pemasaran, adopsi teknologi, sarana produksi dan kebijakan moneter dari tanggapan responden disebutkan berada pada katagori baik dengan rata-rata skor sebesar \pm 3 , artinya bahwa faktor-faktor tersebut dalam katagori baik sehingga cukup mempengaruhi dalam strategi pengembangan agribisnis nanas (Ananas comosus L.Merr.) di Kabupaten Kediri Jawa Timur.

Tabel 5. Hasil Tangapan Responden Faktor Ancaman

\begin{tabular}{|c|c|c|c|c|c|c|}
\hline \multirow[t]{2}{*}{ No } & Ancaman / Threats & SB & B & KB & TB & \multirow[t]{2}{*}{ Rata-rata } \\
\hline & Skor & 4 & 3 & 2 & 1 & \\
\hline \multirow{2}{*}{\multicolumn{2}{|c|}{ 1. Bencana Alam }} & & 12 & 3 & & \multirow[t]{2}{*}{$42 / 15=2,8$} \\
\hline & & & 36 & 6 & & \\
\hline \multirow{2}{*}{\multicolumn{2}{|c|}{ 2. Nanas Impor }} & & 8 & 6 & 1 & \multirow[t]{2}{*}{$37 / 15=2,4$} \\
\hline & & & 24 & 12 & 1 & \\
\hline \multirow{2}{*}{\multicolumn{2}{|c|}{ 3. Alih Fungsi Lahan }} & & 1 & 11 & 3 & \multirow[t]{2}{*}{$28 / 15=1,8$} \\
\hline & & & 3 & 22 & 3 & \\
\hline \multirow{2}{*}{\multicolumn{2}{|c|}{ 4. Perubahan Musim }} & & 13 & 2 & & \multirow[t]{2}{*}{$43 / 15=2,8$} \\
\hline & & & 39 & 4 & & \\
\hline \multirow{2}{*}{\multicolumn{2}{|c|}{ 5. Hama Penyakit }} & & & 8 & 9 & \multirow[t]{2}{*}{$25 / 15=1,6$} \\
\hline & & & & 16 & 9 & \\
\hline \multirow{2}{*}{\multicolumn{2}{|c|}{ 6. Krisis Ekonomi }} & 1 & 13 & & 1 & \multirow[t]{2}{*}{$44 / 15=2,9$} \\
\hline & & 4 & 39 & & 1 & \\
\hline
\end{tabular}

Keterangan: SB: sangat baik, B: baik, KB: kurang baik, TB: tidak baik

Tabel 5. dijelaskan faktor ancaman seperti bencana alam disebutkan berada pada katagori baik dengan rata-rata skor sebesar \pm 3 , artinya bahwa dari aitem pertanyaan yang diajukan kepada responden memperlihatkan bahwa faktorfaktor tersebut baik mempengaruhi dalam strategi pengembangan agribisnis nanas (Ananas comosus L.Merr.) di Kabupaten Kediri Jawa Timur.

Sedangkan faktor nanas impor, alih fungsi lahan dari tanggapan responden disebutkan berada pada katagori kurang baik dengan ratarata skor \pm 2 , artinya bahwa aitem pertanyaan yang diajukan kepada responden memperlihatkan bahwa faktor-faktor tersebut kurang mempengaruhi dalam strategi pengembangan agribisnis nanas (Ananas comosus L. Merr.) di Kabupaten Kediri Jawa Timur.

Sedangkan faktor perubahan musim dan krisis ekonomi dari tanggapan responden disebutkan berada pada katagori baik dengan rata-rata skor \pm 3 , artinya bahwa aitem pertanyaan yang diajukan kepada responden memperlihatkan bahwa faktor-faktor tersebut mempengaruhi dalam strategi pengembangan agribisnis nanas (Ananas comosus L. Merr.) di Kabupaten Kediri Jawa Timur.

Pada Tabel 6. Internal Strategic foctors Analysis Summary (IFAS) terlihat bahwa Faktor Kekuatan (Strenghts) mempunyai nilai 1,6 sedangkan Faktor kelemahan (Weaknesses) mempunyai nilai 1,35 ini mengandung arti babwa berdasarkan faktor-faktor yang mempengaruhi dalam strategi pengembangan sentra agribisnis nanas (Ananas comosus L.Merr.) di Kabupaten Kediri Jawa Timur, memiliki suatu kekuatan dari dalam yang begitu besar akan tetapi juga mempunyai suatu kelemahan yang cukup besar dan harus diwaspadai.

Kondisi seperti ini memberikan suatu arah strategi pengembangan sentra agribisnis nanas kepada para petani nanas untuk memanfaatkan faktor kekuatan serta meminimalkan faktor kelemahan yang ada. 
Tabel 6. Internal Strategic Factor Analysis Summary (IFAS)

\begin{tabular}{|c|c|c|c|}
\hline Faktor Strategi Internal & Bobot & Rating & Skor \\
\hline \multicolumn{4}{|l|}{ 1. Kekuatan (Strenghts) } \\
\hline - Agroekologi & 0,1 & 4 & 0,4 \\
\hline - Kualitas SDM & 0,1 & 3 & 0,3 \\
\hline - Ketersediaan Bibit & 0,1 & 3 & 0,3 \\
\hline - Ketersediaan Lahan & 0,1 & 3 & 0,3 \\
\hline - Kelembagaan Petani & 0,05 & 3 & 0,15 \\
\hline - Kebijakan Pemerintah Daerah & 0,05 & 3 & 0,15 \\
\hline Sub Total & 0,5 & & 1,6 \\
\hline \multicolumn{4}{|l|}{ 2. Kelemahan (Weaknesses) } \\
\hline - Menejemen Usaha Tani & 0,1 & 3 & 0,3 \\
\hline - Kepemilikan Lahan $<0,5$ ha & 0,1 & 3 & 0,3 \\
\hline - Permodalan / Modal Uang & 0,1 & 3 & 0,3 \\
\hline - Budaya Petani & 0,1 & 2 & 0,2 \\
\hline - Pemupukan Tak berimbang & 0,05 & 2 & 0,1 \\
\hline - Akses Pasar Terbatas & 0,05 & 3 & 0,15 \\
\hline Sub Total & 0,5 & & 1,35 \\
\hline Total & 1 & & 2,95 \\
\hline
\end{tabular}

Tabel 7. External Strategic Factor Analysis Summary (EFAS)

\begin{tabular}{|c|c|c|c|}
\hline Faktor Strategi Eksternal & Bobot & Rating & Skor \\
\hline \multicolumn{4}{|l|}{ 3. Peluang (Opportunities) } \\
\hline - Pengembangan Varietas Baru & 0,1 & 4 & 0,4 \\
\hline - Strategi Pemasaran & 0,1 & 3 & 0,3 \\
\hline - $\quad$ Adopsi Teknologi & 0,1 & 3 & 0,3 \\
\hline - Sarana Produksi & 0,1 & 3 & 0,3 \\
\hline - Kebijakan Moneter & 0,05 & 3 & 0,15 \\
\hline - Industri Pengolahan Hasil Pertanian & 0,05 & 2 & 0,1 \\
\hline Sub Total & 0,5 & & 1,55 \\
\hline \multicolumn{4}{|l|}{ 4. Ancaman (Threats) } \\
\hline - Bencana alam & 0,1 & 3 & 0,3 \\
\hline - Nanas Impor & 0,1 & 2 & 0,2 \\
\hline - Alih Fungsi Lahan & 0,1 & 2 & 0,2 \\
\hline - Perubahan Musim & 0,1 & 3 & 0,3 \\
\hline - Hama Penyakit & 0,05 & 2 & 0,1 \\
\hline - Krisis Ekonomi & 0,05 & 3 & 0,15 \\
\hline Sub Total & 0,5 & & 1.25 \\
\hline Total & 1 & & 2,8 \\
\hline
\end{tabular}

Hasil analisa External Strategic Faktor Analysis Summary (EFAS) pada Tabel 7. terlihat bahwa Faktor peluang (Opportunities) mempunyai nilai 1,55 sedangkan Faktor ancaman (Treats) mempunyai nilai 1,25 ini mengandung arti bahwa berdasarkan faktor-faktor yang mempengaruhi dalam strategi pengembangan sentra agribisnis nanas (Ananas comosus L.Merr.) di Kabupaten Kediri Jawa Timur, terbuka peluang yang begitu lebar akan tetapi juga ada suatu ancaman dari luar yang cukup besar dan harus dicermati.

Kondisi seperti ini memberikan suatu arah strategi pengembangan agribisnis nanas kepada para petani nanas untuk memanfaatkan peluang bisnis yang terbuka lebar serta memperhatikan ancaman yang menghambat usaha agribisnis nanas yang ada. 
Tabel 8. Matrik IFAS dan EFAS

\begin{tabular}{|l|l|l|}
\hline \multicolumn{1}{|c|}{ IFAS } & \multicolumn{1}{|c|}{ STRENGHTS (S) } & \multicolumn{1}{|c|}{ WEAKNESSES (W) } \\
\hline OPPORTUNITIES (O) & $\begin{array}{l}\text { STRATEGI (SO) } \\
1,6+1,55=3,15\end{array}$ & $\begin{array}{l}\text { STRATEGI (WO) } \\
1,35+1,55=2,9\end{array}$ \\
\hline THREATS (T) & STRATEGI (ST) & STRATEGI (WT) \\
& $1,6+1,25=2,85$ & $1,35+1,25=2,6$ \\
\hline
\end{tabular}

\section{B. Tahap Matrik SWOT}

Analisa Matrik IFAS dan EFAS disusun Matrik SWOT untuk menganalisa rumusan alternatif strategi, baik strtegi SO, WO, ST dan WT, dan hasil analisa matrik SWOT seperti pada tabel sebagai berikut :

Tabel 9. Matrik SWOT

\begin{tabular}{|c|c|c|}
\hline $\begin{array}{l}\mathbf{E} \\
\mathbf{F} \\
\mathbf{A} \\
\mathbf{S}\end{array}$ & $\begin{array}{l}\text { STRENGHTS (S) } \\
\text { 1. Agroekologi } \\
\text { 2. Kualitas SDM } \\
\text { 3. Ketersediaan Bibit } \\
\text { 4. Ketersediaan lahan } \\
\text { 5. Kelembagaan Petani } \\
\text { 6. Kebijakan Pemerintah Daerah }\end{array}$ & $\begin{array}{l}\text { WEAKNESSES }(\mathbf{W}) \\
\text { 1. Menejemen Usaha Tani } \\
\text { 2. Kepemilikan Lahan }<0,5 \text { ha } \\
\text { 3. Permodalan /Modal Uang } \\
\text { 4. Budaya Petani } \\
\text { 5. Pemupukan Tak Berimbang } \\
\text { 6. Akses Pasar Terbatas }\end{array}$ \\
\hline $\begin{array}{l}\text { OPPORTUNITIES (O) } \\
\text { 1. Pengem. Varietas baru } \\
\text { 2. Strategi Pemasaran } \\
\text { 3. Adopsi teknologi } \\
\text { 4. Sarana Produksi } \\
\text { 5. Kebijakan Moneter } \\
\text { 6. Industri pengolahan } \\
\text { Hasil Pertanian }\end{array}$ & $\begin{array}{l}\text { STRATEGI (SO) } \\
\text { 1. Agroekologi yang cocok untuk } \\
\text { budidaya nanas dipadu dengan } \\
\text { sumber daya manusia yang tinggi } \\
\text { akan mampu menciptakan buah } \\
\text { nanas unggul dan strategi } \\
\text { pemasaran akan tercipta tren pasar } \\
\text { 2. Ketersediaan bibit, ketersediaan } \\
\text { lahan dan adopsi teknologi akan } \\
\text { mampu menghasilkan nanas } \\
\text { unggul dalam kualitas dan } \\
\text { kontinuitas. } \\
\text { 3. Hasil produksi nanas makin unggul } \\
\text { apabila didukung tersedianya } \\
\text { sarana produksi kebijakan } \\
\text { pemerintah dan moneter yang } \\
\text { memihak pada petani nanas }\end{array}$ & $\begin{array}{l}\text { STRATEGI (WO) } \\
\text { 1. Menejemen usaha tani perlu dibenahi } \\
\text { dan tingkatkan sehingga mampu } \\
\text { menghasilkan nanas unggul. } \\
\text { 2. Kepemilkan lahan yang sempit perlu } \\
\text { didukung adanya varietas baru dan } \\
\text { adopsi teknologi sehingga } \\
\text { menghasilkan nanas unggul produksi } \\
\text { tinggi. } \\
\text { 3. Budaya petani tidak jadi kendala } \\
\text { selama ada pola pemupukan } \\
\text { berimbang,kebijakan moneter, dan } \\
\text { adanya industri pengolahan nanas } \\
\text { akan ada jaminan produksi baik serta } \\
\text { jaminan pasar. }\end{array}$ \\
\hline $\begin{array}{l}\text { THREATS (T) } \\
\text { 1. Bencana Alam } \\
\text { 2. Nanas Impor } \\
\text { 3. Alih Fungsi Lahan } \\
\text { 4. Perubahan Musim } \\
\text { 5. Hama Penyakit } \\
\text { 6. Krisis Ekonomi }\end{array}$ & $\begin{array}{l}\text { STRATEGI (ST) } \\
\text { 1. Kecocokan agroekologi dan } \\
\text { kualitas sumber daya manusia } \\
\text { harus mampu meminimalisir } \\
\text { bencana alam. } \\
\text { 2. Ketersediaan bibit dan ketersediaan } \\
\text { lahan harus mampu menghasilkan } \\
\text { nanas unggul guna menyaingi } \\
\text { adanya nanas impor. } \\
\text { 3. Kelembagan tani harus mampu } \\
\text { memenet agribisnis nanas guna } \\
\text { mengantisipaksi } 4 \text { dampak } \\
\text { perubahan musim dan hama } \\
\text { penyakit serta kebijakan } \\
\text { pemerintah harus mampu } \\
\text { mengatisipasi krisis ekonomi }\end{array}$ & $\begin{array}{l}\text { STRATEGI (WT) } \\
\text { 1. Kombinasi menejemen usaha tani dan } \\
\text { ketersediaan modal akan dapat } \\
\text { mengantisifasi bencana alam serta } \\
\text { mampu menghasilkan nanas unggul } \\
\text { berkualitas sehingga dapat } \\
\text { menghadapi nanas impor. } \\
\text { 2. Kendala alih fungsi lahan, perubahan } \\
\text { musim,hama penyakit tidak menjadi } \\
\text { halangan dalam menghasilkan nanas } \\
\text { unggul dan disukai pasar. } \\
\text { 3. Kendala krisis ekonomi tidak menjadi } \\
\text { halangan selama kualitas nanas } \\
\text { unggul disukai konsumen dan dapat } \\
\text { menembus pasar modern dan industri } \\
\text { pengolahan hasil pertanian. }\end{array}$ \\
\hline
\end{tabular}




\section{Matrik Kuantitatif SWOT}

Tabel 10. Matrik Kuantitatif SWOT

\begin{tabular}{|c|c|c|}
\hline EFAS IFAS & $\begin{array}{l}\text { STRENGHTS (S) } \\
\qquad(1,6)\end{array}$ & $\begin{array}{c}\text { WEAKNESSES (W) } \\
(1,35)\end{array}$ \\
\hline $\begin{array}{c}\text { OPPORTUNITIES (O) } \\
\qquad(1,55)\end{array}$ & $\begin{array}{l}\text { STRATEGI (SO) } \\
\text { Menggunakan kekuatan internal untuk } \\
\text { memanfatkan peluang eksternal } \\
\text { sebesar-besarnya } \\
\quad=3,15\end{array}$ & $\begin{array}{l}\text { STRATEGI (WO) } \\
\text { Meminimalkan kelemahan } \\
\text { internal untuk memanfaatkan } \\
\text { peluang eksternal yang ada } \\
\quad=2,9\end{array}$ \\
\hline $\begin{array}{r}\text { THREATS (T) } \\
(1,25)\end{array}$ & $\begin{array}{l}\text { STRATEGI (ST) } \\
\text { Menggunakan kekuatan internal untuk } \\
\text { mengatasi ancaman eksternal secara } \\
\text { intensif } \\
\quad=2,85\end{array}$ & $\begin{array}{l}\text { STRATEGI (WT) } \\
\text { Meminimalkan kelemahan } \\
\text { internal untuk menghindari dan } \\
\text { mengatasi ancaman eksternal } \\
\quad=2,6\end{array}$ \\
\hline
\end{tabular}

Hasil Tabel 10. menunjukan bahwa pengembangan sentra agribisnis nanas (Ananas comosus L.Merr.) di Kabupten Kediri, Jawa Timur, alternatif yang paling tepat adalah dengan menggunakan strategi SO, karena strategi tersebut mempunyai nilai tertinggi, yaitu sebesar 3,15 dimana pada strategi SO ialah strategi menggunakan kekuatan untuk memnfaatkan peluang agar petani nanas mampu mengembangkan sentra agribisnis nanas (Ananas comosus L.Merr.) di Kabupaten Kediri Jawa Timur, sehingga akan didapatkan keuntungan yang optimal, dengan alternatif strategi sebagai berikut :

a. Agroekologi yang cocok untuk budidaya nanas dipadukan dengan sumberdaya manusia yang tinggi akan mampu menciptakan strategi pemasaran dan jaringan pemasaran serta mampu mengikuti tren pasar dalam kompetisi buah nanas.

b. Ketersediaan varietas unggul dan dipadukan dengan adopsi teknologi perbanyakan bibit kultur jaringan serta introduksi bibit unggul baru akan menciptakan produk buah nanas yang berkualitas.

c. Produksi nanas akan semakin berkualitas dan kontinuitas apabila tersedia sarana produksi dan didukung kebijakan pemerintah yang memihak pada petani nanas.

\section{Kesimpulan}

Berdasarkan pada analisa SWOT dengan beberapa tahapan analisa yang dilakuakan sampai akhirnya menghasilkan Tabel Matrik Kuantitatif SWOT, maka dapat disimpulkan sebagai berikut :
1. Dalam pengembangan nanas di Kabupaten Kediri, faktor-faktor internal yang menjadi kekuatan meliputi (a) agroekologi yang cocok (b) SDM berkualitas (c) Ketersediaan bibit unggul hasil penangkaran sendiri (d) Ketersediaan lahan (e) Kelembagaan Petani mantap (f) kebijakan pemerintah yang memeihak petani nanas, sedangkan faktor-faktor internal yang menjadi kelemahan meliputi : (a) Menejemen usaha tani masih tradisional (b) Kepemilikan lahan petani rata-rata dibawah 0,5 ha (c) Permodalan terbatas (d) Budaya petani yang masih kolot (e) Pemupukan tak berimbang (f) Akses pasar petani terbatas (belum bisa menjadi penentu harga). Sementara faktor-faktor eksternal yang menjadi peluang meliputi (a) Pengembangan varietas baru (b) Strategi pemasaran (c) Adopsi teknologi kultur jaringan (d) Ketersediaan sarana produksi (e) kebijakan moneter (f) Adanya industri pengolhan nanas, sedangkan faktor-faktor eksternal yang menjadi ancaman meliputi : (a) Bencana Alam (b) Nanas impor (c) Alih funsi lahan (d) Perubahan musim (e) Hama Penyakit (f) Krisis ekonomi

2. Dari hasil analisis SWOT strategi yang paling epetif dan efisien untuk pengembangan nanas (Ananas comosus L.Merr) di Kabupaten Kediri adalah strtegi SO dengan nilai tertinggi sebesar 3,15 yaitu dengan memaksimalkan kekuatan (strenghts) yang ada untuk memanfaatkan peluang (oppotunities) yang tersedia maka petani nanas akan mendapatkan keuntungan yang optimal. 


\section{Daftar Pustaka}

Ali Musa Pasaribu 2012, Perencanaan dan Evaluasi Proyek Agribisnis. Andi, Yogyakarta.

Almasdi Syahza DKK, 2007, Strategi Pengembangan Industri Pengolahan Nenas Sebagai upaya percepatan ekonomi masyarakat pedesaan dikabupaten Bengkalis. lembaga penelitian Universitas Riau Pekan Baru.

Akuba Rusthamrin. 2003. Visi kelembagaan perkelapaan Indonesia di era otonomi Daerah. Proseding Konfrensi Kelapa V, Tembilahan, Oktober 2002. Hlm 133-136.

Arsyad dkk. Dalam Sukartawi, 1995, Agribisnis, Teori dan Aplikasinya, PT Raja Grafindo, Jakarta

Bungaran Saragih 2001, Peranan Publik Relation dan Pembangunan Pertanian, Makalah Seminar, Institut Pertanian Bogor.

Beattie, B. R., and C. R. Taylor. 1996 . Ekonomi Produksi. Penerbit Gajah Mada University Press, Yogyakarta.

Bilas, R. 1992. Teori Mikro Ekonomi. Penerbit Erlangga Jakarta.

Badan Pusat Statistik dan Direktorat Jenderal Hortikultura. 2013. Ekspor Buah Nanas Tahun 2008-2012. http://www.deptan.go.id/ekspor-buahnanas.pdf [21 Mei 2013].

Badan Pusat Statistik dan Direktorat Jenderal Hortikultura. 2013. Produksi dan Konsumsi Buah Nanas Tahun 2008-2012. http://www.deptan.go.id/prod-konsumsibuah.pdf [4 Juni 2013].

Ditjen Bina Produksi Hortikultura. 2003. Standar Prosedur Operasional (SOP) Pendekatan Jaminan Mutu Nanas.Jakarta.

Direktorat Tanaman Buah, Ditjen Hortikultura. 2004. Vademekum Nanas (Ananas comosus L. Merr.)

Departemen Pertanian. 2007. Prospek Dan Arah Pengembangan Agribisnis Bawang Merah. Departemen Pertanian. Bogor. htpp://www.litbang.deptan.go.id [10 Juli 2010].
Diperta Kab. Kediri. 2009. Laporan Tahunan 2009. Dinas Pertanian Tanaman Pangan. Pemerintah Kabupaten Kediri.

Dirjen PPHP Deptan. 2007. Penanganan Pasca Panen Buah. Direktorat Jenderal Pengolahan Dan Pemasaran Hasil Pertanian Departemen Pertanian. Jakarta.

Hasni, H. 2004. Evaluasi Pola Pemanfaatan Sumber Daya Lahan di Antara Kelapa Dengan Tanaman Sela, Berdasarkan Kajian Aspek Sosek dan Konservasi Lahan. Disertasi Doktor, Sekolah Pasca Sarjana IPB 2002.192 pp.

Intan Rahmawati dan Akram. (2007). Faktorfaktor yang Mempengaruhi Kebijakan Dividen dan Pengaruhnya Terhadap Nilai Perusahaan Pada Perusahaan-perusahaan di BEJ. Jurnal Riset Akuntansi, 6(1).

J. David Hunger dan Thomas L Whalen 2003, Manajemen Strategis. Andi Yogyakarta.

Jabal Tarik Ibrahim dkk 2012, Pola pembiayaan (Lending Model) Budidaya Nanas. Fakultas Pertanian dan Peternakan Universitas Muhammadiyah malang, Malang 1997.

Lisdiana dan Widyaningsih Soemardi, Budidaya Nenas, C.V. ANEKA, Solo 2012 Standart Operating Procedur (SOP) Nenas Smooth Cayenne Kabupaten Kediri, Direktoral budidaya dan Pasca panen buah, Direktorat Jenderal Hortikultura Kementrian Pertanian.

Luntungan. H.T., Effendi. D, Supriadi. H. dan Damanik, S. 2005. Laporan Kegiatan Peningkatan Pendapatan Petani Kelapa di Riau.

Nicholson, W. 1999. Teori Ekonomi Mikro Prinsip Dasar dan Pengembangannya. Radja Grefindo Persada. Jakarta. Freddy Rangkuti, 2008, Analisis SWOT, Teknik Membedah Kasus Bisnis, PT Gramedia Pustaka Utama, Jakarta.

Nuhung,I.A, 2007. Membangun Pertanian Masa Depan. CV. Aneka Ilmu, Semarang.

Pusat Kajian Buah Tropika (PKHT) Institut Pertanian Bogor (IPB). Pedoman Penerapan Penerapan Jaminan Mutu Terpadu Nanas. LPPM Institut Pertanian Bogor . Bogor. 
Rangkuti Freddy, 2002, Analisis SWOT, Teknik Membedah Kasus Bisnis. Cetakan ke-9. PT Gramedia Pustaka Utama, Jakarta.

Suryabrata Sumadi, 1981, Pedoman Penelitian. CV. Rajawali. Jakarta

Rangkuti Freddy, 2008, Analisis SWOT, Teknik Membedah Kasus Bisnis. PT Gramedia Pustaka Utama, Jakarta.

Rangkuti Freddy, 2013, SWOT Balanced Scorecard (Teknik Menyusun Strategi Korporat Yang Efektif Plus Cara Mengelola Kinerja dan Resiko). PT. Gramedia Pustaka Utama, Jakarta.

Saragih, B. 2001. Membangun Sistem Agribisnis. Suara dari Bogor. Yayasan USESE, Pustaka Wirausaha Muda. Edisi kedua. Bogor. 206 hlm.

Sudarman, A. dan Alghifari. 1992. Ekonomi Mikro. BPFE. Yogyakarta.

Suprapto, A. 1998. Prospek Pengembangan Agribisnis Kelapa Dalam Era Globalisasi. Prosiding Konperensi Nasional Kelapa IV. Bandar Lampung, tgl 21-23 April 1998. Hlm 77 - 98.

Said.E.G. dan Intan. AH, 2001. Manajemen Agribisnis. Ghalia Indonesia

Soekarwi,2003. Agribisnis; Teori dan Aplikasinya. Raja Grafindo Persada, Jakarta.

Sabarman Damanik. 2007, Strategis pengembangan Agribisnis Kelapa untuk meningkatkan pendapatan petani di kabupaten Idragiri hilir Riau. Pusat Penelitian Dan Pengembangan.

Wicaksono. 2015. Produksi Tanaman Nanas (Ananas Comosus (L.) Merr.). Fakultas Pertanian. Prodi. 